\title{
Development of Interactive Learning Media with Construct 2 Software to X Graders Student on The Trigonometry Material
}

\author{
Ida Siti Mahsunah \\ Department of Mathematics Education \\ Yogyakarta State University \\ Yogyakarta, Indonesia \\ idasm27@gmail.com
}

\author{
Nur Hadi Waryanto \\ Department of Mathematics Education \\ Yogyakarta State University \\ Yogyakarta, Indonesia \\ nur_hw@uny.ac.id
}

\begin{abstract}
This research is a developmet research that aims to describe the steps of development, to know the quality, and to know the students` responses of an interactive learning media on the trigonometric material in the form of android application. The results of the research are: (1) the development of the learning media using DDD-E model whitch consists of four steps of decide, design, develop, and evaluate, (2) the quality of the developed learning media according to media expert, material expert, and mathematics teacher included to the "good" category with the mean score of $4.08,3.96$, and 4,04 respectively from maximal score is $5,(3)$ the students' responses to interactive learning media developed were include in the "positive" category with the total average percentage was $79.23 \%$ and the "good" rating was $56.96 \%$.
\end{abstract}

\section{Keywords-interactive learning media; mathematics learning}

\section{INTRODUCTION}

Trigonometry is one of the compulsory mathematics material studied in secondary school. It is a complex topic because requiring integration of different algebraic, geometric, and graphical aspects. Trygonometry is study of triangles and the relationships between their sides angles. Fourier Transform which is based on sine functions and cosine fuctions is one of trigonometry uses. It is of the primary mathematical tools used in many modern device that people use in their daily life such as portable phone, digital cameras, digital TVs, computer image proccessing, and the internet [1].

Report state that student mastery of trigonometry is still less than $51 \%$ as shown in Table I [2]. It indicated that student mastery of trigonometry is still less. There are many reasons that makes it happen. One of them is ineffectively learning process in classroom, beside trigonometry is a difficult topic because its complex nature. Based on the observasion and direct interview, the mathematics learning process is monoton and still on teacher centered where students had just listening explanation, paying attention, taking notes and answering questions [3] that made the students feel bored and ignored the lesson. In addition, the presentation that was used by teacher as learning media can make students more exited because its looks unattractive and students can not interacting directly with that. Supposedly, the use of learning media in the learning process will lead to more interesting learning so can foster student learning motivation, learning materials more clearly so students more easily to understand and better to achieve the goal of learning, teaching methods will be more varied, not merely verbal communication through the words by the teacher so that students are not bored and the teacher is not exhausted, and the students do more learning activities because not only listen to the teacher's description, but also other activities such as observing, performing, demonstrating, and others [4]. Moreover, during the class there are students who in secret play their smartphone (not to support the lesson) because not interested in what teacher explanation and feel bored.

TABLE I. TRIGONOMETRY MASTERY OF SENIOR HIGH SCHOOL IN 2015/2016

\begin{tabular}{|l|c|c|c|}
\hline \multicolumn{1}{|c|}{ Competence } & $\begin{array}{c}\text { City } \\
\text { (Yogyakarta) }\end{array}$ & $\begin{array}{c}\text { Province } \\
\text { (DIY) }\end{array}$ & National \\
\hline $\begin{array}{l}\text { Resolve a reasoning } \\
\text { problem related to } \\
\text { trigonometry }\end{array}$ & 46,50 & 43,28 & 47,51 \\
\hline $\begin{array}{l}\text { Calculate trigonometric } \\
\text { ratio value by using the sum } \\
\text { formula of two angles and } \\
\text { the difference formula of } \\
\text { two angles }\end{array}$ & 56,50 & 46,97 & 50,41 \\
\hline $\begin{array}{l}\text { Resolving trigonometric } \\
\text { equations }\end{array}$ & 31,58 & 26,37 & 40,47 \\
\hline $\begin{array}{l}\text { Resolve daily issues related } \\
\text { to trigonometry }\end{array}$ & 37,92 & 29,20 & 41,37 \\
\hline $\begin{array}{l}\text { Resolving issues related to } \\
\text { trigonometric ratios }\end{array}$ & 36,85 & 30,08 & 39,35 \\
\hline
\end{tabular}

Indeed, to overcome these problems need considering the development of technology and sciences. In this globalization era, technology and sciences develop so fast. Mobile learning or m-learning emergence is one of that impact. M-learning is learning supported primarily by handheld and mobile technologies such as smarthphone and netbook [5]. Report state that $41 \%$ of smartphone user in student [6]. It means that developing an interactive learning media that interesting and using smartphone to operate could become a solution to these problems.

The interactive learning media presented in game format. This format was chosen because the positive effect of game on conceptual understanding, problem solving, spatial ability, 
critical thinking, automaticity, and a host of other higher order thinking skills [5]. Furthermore, to support this format the interactive learning media was developed using Construct 2 software. The product of this reseacrh is an android application.

Therefore, this research is aimed to develop interactive learning media with Conctruct 2 software on trigonometry material, to know the quality of the developed interactive learning media according to media expert, material expert, and mathematics teacher, and to know the student`s responses.

\section{RESEARCH METHOD}

Type of this research is research and development $(\mathrm{R} \& \mathrm{D})$ to develop an interactive learning media with Construct 2 software to $\mathrm{X}$ graders student on the trigonometry material. It conducted on June 2017 in SMA N 11 Yogyakarta. The subject of this research was thirty-two students of X (ten) grade in SMA N 11 Yogyakarta.

The development model of this research is DDDE model which consists of four stages: decide, design, develop, and evaluate. Decide aimed to determine the software and hardware that will be used with consider the effectiveness of developing learning media in improving learning outcomes, the suitability of learning media with students, the appropriateness of learning media with the current curriculum, and the ability of students in using the hardware that will be used to operate the learning media. Decide consist of determine the format of learning media, the software that will used to develop the learning media, and the hardware that will be used to operate the learning media. Design aimed to design the learning media based on the format of learning media that was chosen. Design consist of arranging material, creating flowchart, storyboard, and deciding assessment instrument. In addition, it created some instrument to assess the quality of learning media. Develop aimed to produce the learning media based on design of learning media using the software that has been decided. Evaluate aimed to revise the developed learning media based on the suggestions and comment obtained from questionnaire or implementation notes. Evaluate consists of evaluating by media expert and evaluating by material expert That evaluation did before the learning media was implemented to the students. It also consist of evaluating by student and evaluating by mathematics teacher did after students tried to study with the developed learning media.

The data of this research consists of evalution dan response data. Data of evaluation is gotten from the average of evaluation score from media expert, the average of evaluation score from material expert, and the average of evaluation score from mathematics teacher. Data of response is gotten from the average score of students` responses. Besides, there are some data gotten from suggestions and comments obtained from questionnaire or implementation notes.

Instruments are established by considering three aspects of learning media evaluation and seven aspects of questionnaire user response. The three aspects of learning media evaluation are software engineering aspect, learning design aspect, and visual communication aspect [7]. Whereas the seven aspects of questionnaire user response are happiness, curiosity, liveness, attention, interesting, spirit, and easiness [8].

Data analyzes is used to know the quality of the developed learning media based on media expert, material expert, and mathamatics teacher and to know the student response of the developed learning media. The quality of the developed learning media based on media expert, material expert, and mathamatics teacher can be analyzed by several steps such as data tabulation, calculate the everage score, and convert the everage score into qualititative criteria based on Table II [8].

TABLE II. DATA CONVERSION CRITERIA

\begin{tabular}{|c|c|}
\hline Interval Score & Category \\
\hline $\bar{x}>\bar{x}_{l}+1,8 S b_{i}$ & Very Good \\
\hline $\bar{x}_{l}+0,6 S b_{i}<\bar{x} \leq \bar{x}_{l}+1,8 S b_{i}$ & Good \\
\hline $\bar{x}_{l}-0,56<\bar{x} \leq \bar{x}_{l}+0,6 S b_{i}$ & Enough \\
\hline $\bar{x}_{l}-1,8 S b_{i}<\bar{x} \leq \bar{x}_{l}-0,6 S b_{i}$ & Less Good \\
\hline $\bar{x} \leq \bar{x}_{l}-1,8 S b_{i}$ & Very Less \\
\hline
\end{tabular}

According to Table II, it can be determined the interval of evaluation of the developed learning media as shown in Table III.

TABLE III. THE INTERVAL OF LEARNING MEDIA QUALITY

\begin{tabular}{|c|c|}
\hline Interval Score & Category \\
\hline $\bar{x}>4,2$ & Very Good \\
\hline $3,4<\bar{x} \leq 4,2$ & Good \\
\hline $2,6<\bar{x} \leq 3,4$ & Enough \\
\hline $1,8<\bar{x} \leq 2,6$ & Less Good \\
\hline $\bar{x} \leq 1,8$ & Very Less \\
\hline
\end{tabular}

The developed learning media fulfills the good quality if it can achieve the minimum criteria is good and validator state that this developed product can be impemented with revision

The student response can be analyzed by several steps such as data tabulation, calculate the everage of total respon persentage (RT), and convert the of total respon persentage into qualititative criteria based on Table IV [9].

TABLE IV. THE INTERVAL OF RESPONSE CRITERIA

\begin{tabular}{|c|c|}
\hline Interval Score & Category \\
\hline$R T \geq 85 \%$ & Very Positive \\
\hline $70 \% \leq R T<85 \%$ & Positive \\
\hline $50 \% \leq R T<75 \%$ & Less Positive \\
\hline$R T<50 \%$ & Not Positive \\
\hline
\end{tabular}

The calculation result of data student response was used to know the student response to the developed learning media.

\section{RESULT AND DISCUSSION}

Developing learning media of this research using DDDE model consists of four stages: decide, design, develop, and evaluate. First, deciding to use Construct 2 softwere to develop learning media because the format of learning media that was chosen is game and use smartphone based on android system as hardware to operate the developed learning media. It was chosen with consider the current curriculum, characteristics of students, 
and the ability of students in using the smartphone. In addition, learn about Construct 2 software, discussion, interview with teacher and student, and observation of learning process in the class did in this stage. In addition, student learn by making sense of the environment stimuli around them [10]. Therefore, game was chosen to be the format of learning media to stimulate student learning trigonometry.

Second, designing the learning media. Design consist of material analysis and then arranging the material, creating flowchart, storyboard, and deciding assessment instrument. In addition, it created some instrument to assess the quality of learning media. It resulted the name of leaning media application that is Super Mario Math, the learning media is game application consists of five level there are first level for appeception, second level for sinus rules topic, third level cosinus rules topic, fourth level for triangle area topic, and fifth level for evaluation, the flowchart that showing the path of learning media, the storyboard that imaging the view of learning media, and the instrument of evaluation of learning media. Super Mario Math was chosen as the name of this game because the concept of this game adopted from Super Mario games. This game consists of some level because the interesting part of a game is challange and mistery that should be solved [11].

Third, developing or producing the leraning media based on design of learning media. Developing learning media consist of collecting and creating the components that was needed such as picture, audio, and teks, producting the learning media using Contruct 2 software, and converting the learning media into android application. Construct 2 software was chosen because it is an editor game based on HTML5 (Hyper Text Markup Language) with many fitures such as multiple platforms to target, no programming language required, built-in physics, extensible, dan special effects [12].

Fourth, evaluate the learning media. the evaluation did twice. Firstly learning media was evaluated by media expert and material expert before the learning media was implemented in the class. This evaluation aimed to know the quality and to revise the learning media. The evaluation result was shown in Table $\mathrm{V}$ and Table VI.

TABLE V. THE EVALUATION RESULT BY MEDIA EXPERT

\begin{tabular}{|c|c|c|c|c|}
\hline Aspect & $\begin{array}{c}\text { Average } \\
\text { Score }\end{array}$ & Criteria & Average & Quality \\
\hline Software Engineering & 4 & Good & \multirow{3}{*}{4,08} & \multirow{3}{*}{ Good } \\
\hline Learning Design & 4 & Good & & \\
\hline Visual Communication & 4,2 & Good & & \\
\hline
\end{tabular}

TABLE VI. THE EVALUATION RESULT BY MATERIAL EXPERT

\begin{tabular}{|l|c|c|c|c|}
\hline \multicolumn{1}{|c|}{ Aspect } & $\begin{array}{c}\text { Average } \\
\text { Score }\end{array}$ & Criteria & Average & Quality \\
\cline { 1 - 3 } Learning Design & 3,95 & Good & \multirow{2}{*}{3,96} & Good \\
\hline Visual Communication & 4 & Good & & \\
\hline
\end{tabular}

Based on the result, the quality learning media was good according to both of media expert and material expert.
Furthermore, the learning media was implemented in the class to 32 students grade X of SMA N 11 Yogyakarta and was evaluated by student and mathematics teacher after that. This evaluation aimed to know the student response and the quality of the learning media and to revise the learning media. The evaluation result was shown in Table VII and Table VIII.

TABLE VII. THE PERCENTAGE OF STUDENT RESPONSE

\begin{tabular}{|l|c|l|c|c|}
\hline \multicolumn{1}{|c|}{ Aspect } & $\begin{array}{c}\text { Average Score } \\
(\mathbf{\%})\end{array}$ & Criteria & $\begin{array}{c}\text { Average } \\
(\boldsymbol{\%})\end{array}$ & Quality \\
\hline Happiness & 82,08 & Positive & & \\
\hline Curiosity & 79,69 & Positive & & \\
\cline { 1 - 3 } Interesting & 82,19 & Positive & \multirow{2}{*}{79,23} & \multirow{2}{*}{ Positive } \\
\hline Attention & 75,94 & Positive & \\
\cline { 1 - 3 } Easiness & 78,75 & Positive & & \\
\cline { 1 - 3 } Doing Task & 76,56 & Positive & & \\
\hline Easiness & 79,38 & Positive & & \\
\hline
\end{tabular}

TABLE VIII.

THE EVALUATION RESULT BY MEDIA EXPERT

\begin{tabular}{|l|c|c|c|c|}
\hline \multicolumn{1}{|c|}{ Aspect } & $\begin{array}{c}\text { Average } \\
\text { Score }\end{array}$ & Criteria & Average & Quality \\
\hline Software Engineering & 5 & Very Good & 4,04 & Good \\
\hline Learning Design & 3,89 & Good & & \\
\hline Visual Communication & 4,14 & Good & & \\
\hline
\end{tabular}

Based on the result, the student response of the learning media was positive with $56,96 \%$ had assessment "good" and the quality learning media was good according to mathematics teacher.

In summary, the developed learning media wa an android application on game format. It consists of five level thare are first level for appeception, second level for sinus rules topic, third level cosinus rules topic, fourth level for triangle area topic, and fifth level for evaluation. The development model of this research is DDDE model which consists of four stages: decide, design, develop, and evaluate. The data of this research consists of evaluation and response data. The developed The developed interactive learning media with Construct 2 software to $\mathrm{X}$ graders student on the trigonometry material was good quality according to media expert, material expert, and mathematics teacher and had positive response from the student.

\section{CONCLUSION}

Based on the result of research, it concluded that 1) the development of inteactive learning media with Construct 2 software to $\mathrm{X}$ graders student on the trigonometry material using DDDE model consists of four stage that are decide, design, develop, and evaluate. Decide stage consist of deciding the format of learning media is game, deciding Construct 2 software to develop the learning media, and decide android smarthphone to operate the learning media. Design stage consist of material analysis and then arranging the material, creating flowchart, storyboard, and deciding assessment instrument created some instrument to assess the quality of the learning media. Development stage consist of developing learning media. Evaluate stage consist evaluate the learning media by media exerts, material expert, mathematics teacher, and student. In addition, revising the learning media based on the suggestions 
and comments obtained from questionnaire or implementation notes. 2) The developed interactive learning media with Construct 2 software to $\mathrm{X}$ graders student on the trigonometry material was good quality according to media expert, material expert, and mathematics teacher with the mean score of 4.08 , 3.96, and 404 respectively from maximal score is 5. 3) The developed interactive learning media with Construct 2 software to $\mathrm{X}$ graders student on the trigonometry material had positive response from student with the total average percentage was $79.23 \%$ and the "good" rating was $56.96 \%$.

\section{RECOMMENDATION}

The developed interactive learning media with Construct 2 software to $\mathrm{X}$ graders student on the trigonometry material was required good quality from media expert, material expert, and mathematics teacher and had positive response from student. Therefore, it can be used for students or teachers to support learning activities in the classroom or to support individual learning in everywhere.

\section{REFERENCES}

[1] A. Sultan and A. F. Artzt, "The Mathematics that Every Secondary School Math Teacher Needs to Know," UK: Routledge, 2011.

[2] Puspendik, "Laporan Hasil Ujian Nasional Tahun Ajaran 2015/2016,“ (application).

[3] I. A. Kusuma and Sahid, "The Development of Student Worksheet Based on Saintific Approach on Linier Programming", 4th ICRIEMS
Proceedings, The Faculty Of Mathematics And Natural Sciences, Yogyakarta State University, ME-27, 2017, in press.

[4] Masduki and A.G. Nugoroho, "Pembelajaran Matematika dengan Media Berbasis Komputer Ditinjau dari aktivitas belajar Siswa." Prosiding Seminar Nasional Penelitian Pendidikan dan Penerapan MIPA, Yogyakarta, PM160, 2011, in press.

[5] N. Dabbagh, A. Denham, M Al-Freih, H. Fake, A. D. Benson, R. Joseph, G. Zgheib, and Z. Guo, "Learning Technologies and Globalization Pedagogical Frameworks and Applications," New York: Springer.

[6] DI Marketing, "Smartphone Usage in Indonesia," accessed 25 April 2017, http://www.di-onlinesurvey.com/en/2016/07/07/smartphone-usage-inindonesia/, 2016.

[7] R.S. Wahono, "Aspek dan Kriteria Penilaian Media Pembelajaran,". accesed $24 \quad$ February 2017 http://romisatriawahono.net/2006/06/21/aspek-dan-kriteria-penilaianmedia-pembelajaran/, 2016.

[8] E.P. Widoyoko, "Evaluasi Program Pembelajaran," Yogyakarta: Pustaka Pelajar, 2009.

[9] Y. Yamasari, "Pengembangan media Pembelajaran Matematika Berbasis ICT yang Berkualitas," Seminar Nasional Pascasarjana X-ITS, Surabaya, 4 Agustus 2010, in press.

[10] L. D. Hammond, K, Austin, S. Orcutt, and J. Rosso, "Episode \#1 Introducition Chapte How People Learn: Introduction to Learning Theories," accesed 6 February 2017, https://web.stanford.edu/class/ed269/hplintrochapter.pdf., 2001.

[11] G. Kurubacak and H. Altinpulluk, "Mobile Technologies and Augmented Reality in Open Education," United States of America: IGI Global, 2017.

[12] A. Subagio, “Learning Construct 2,". Birmingham: Packt Publishing Ltd., 2014. 